\title{
FACULTY DEVELOPMENT FOR E-LEARNING: A MULTI-CAMPUS COMMUNITY OF PRACTICE (COP) APPROACH
}

\author{
Janet Resop Reilly \\ Christine Vandenhouten \\ Susan Gallagher-Lepak \\ University of Wisconsin, Green Bay \\ Penny Ralston-Berg \\ The Pennsylvania State University
}

\begin{abstract}
Faculty development is a critical process, enabling instructors to remain abreast of new discipline specific content and innovations in the scholarship of teaching and learning. The explosion of online higher education and advances in technology provide examples and rationale for why faculty development for elearning is needed. Literature on faculty development and e-learning is reviewed and a multi-campus faculty development program using distance technology and a community of practice model for nursing educators will be described. Successful strategies, barriers and an evaluation of the multi-campus faculty development model experience will be presented in a format that allows for replication across disciplines.
\end{abstract}

\section{KEYWORDS}

Faculty development, e-learning, online teaching, community of practice

\section{INTRODUCTION}

Online learning is an emergent delivery method and strategy in higher education. The Sloan Foundation, a consortium of higher education institutions and organizations, reported that approximately 5.6 million students in the U.S. were enrolled in at least one online course in fall semester of 2009. This represents $21 \%$ growth in online enrollments, compared to a mere $2 \%$ growth in the overall population of higher education students [1]. As the number of e-learning students expands, so too does the demand for quality instruction in the virtual classroom. Faculty are often ill prepared to adopt instructional and pedagogical strategies necessary for online teaching and learning. Online faculty need to learn new methods of teaching, communicating, and working with new technologies, just as online students need to transition to new ways of learning when moving from face-to-face, traditional classrooms to virtual classrooms [2, 3].

Little has been reported about how to best accomplish faculty development in e-learning [4]. This is particularly relevant since the majority of current faculty learned in traditional classrooms, while students coming from primary schools today have already used a plethora of online technologies. So what is the best strategy for strengthening faculty skills in online technology and to prepare faculty to be accomplished online instructors?

A virtual format for faculty development can be an efficient and cost-effective method [5]. Faculty learning communities are an example of faculty development that can connect geographically and demographically diverse individuals from multiple schools to collaboratively achieve common purposes 
or solve real problems [6]. This article details the model, process, strategies, barriers and successes of a year of faculty development completed via a virtual faculty learning community, or community of practice (COP).

\section{FACULTY DEVELOPMENT BASICS}

Faculty development refers to planned activities designed to improve the knowledge, attitudes and skills essential to the performance of the instructor role. McQuiggan and Ragan succinctly described the goal of faculty development to "develop and support a dedicated, skilled (competent) and confident faculty to address the instructional needs of learners" (PowerPoint slide 13)[7]. Evidence of successful faculty development with online learning can be increased enrollment, student satisfaction, faculty satisfaction with the online teaching experience, and faculty desire to participate in online programs [7].

\section{A. Faculty knowledge and skills in e-learning pedagogy}

Faculty development activities must take into account not only faculty predisposition and readiness to adopt technology innovations, but also instructor skill [8]. Wilson and Stacey approached faculty development for online teaching based on Roger's theory of adoption of technology and instructor readiness levels. This theory suggests that people are more or less inherently predisposed to innovative behavior [9]. Early adopters, the $13.5 \%$ of the population that take up and use the innovation readily, see innovations as fun and challenging. The mainstream majority of instructors, however, are pragmatic, conservative, averse to risk, and seek proven innovations [8].

Skill building for online instruction of faculty can be designed around readiness levels. Wilson and Stacy describe this process as "staging a change process." [8]. Strategies need to match the type of instructor. For example, "novice instructors" (who are aware of innovations in technology but have varying interest in applying these) may benefit most from "show and tell" activities, guest speakers, and short seminars describing current activities in their own institutions. "Advanced beginner" instructors value instruction focused on instructional design skills, pedagogy, role play, and reflective activities, while "skillfully advanced" online instructors want to try new strategies in the online learning environment. Along with "advanced beginner" instruction, "skillfully advanced instructors" appreciated instruction on more complex forms of interactivity, like collaborative group learning and case studies. The "advanced, proficient, expert" instructor may be engaged in the research and design of faculty development, serving as both role model and resource for the novice instructor [8].

\section{B. Faculty attitudes about e-learning}

Not all faculty embrace e-learning. Geoghegan described a chasm between early adopters of technology in higher education and the much larger group of faculty who are unengaged in distance education [10]. Major concerns expressed by faculty include the new role of faculty in e-learning (facilitator vs. sage), limited personal face-to-face interaction with students, possible loss of control over intellectual property, increased workload (e.g., online course development), and time required to learn online technologies [11]. Additionally, despite widespread use of computers and other technologies in education, some faculty remain apprehensive (or have cyberanxiety) in moving a course online.

The literature review identified multiple strategies to engage reluctant faculty in e-learning and overcome barriers. Chaney found faculty less likely to teach online were more likely to do so if they had appropriate training [12]. However, mandated faculty development can be problematic. Weaver, Robbie, and Borland found negative attitudes prevailed among faculty when they were mandated to attend faculty development programs with the expectation that they would apply e-learning knowledge in a newly implemented platform [13]. Strategies found to be helpful in overcoming barriers to faculty development include offering faculty compensation and incentives for developing online courses, acknowledgement of the skills needed and developed in tenure and promotion processes, and allowing sufficient time to prepare (which can be 5-6 months) for online instruction [11]. Instructional designers and other support staff can engage faculty by sharing examples of successes from their own portfolios, providing scholarly evidence 
Faculty Development for E-learning: A Multi-campus Community of Practice (COP) Approach

in support of online learning, and telling stories about their own engagement and passion for online learning with faculty [14].

\section{Expanded faculty roles in e-learning}

Roles taken on by online educators include content facilitator, course designer, collaborator and technologist [15]. Considering the multiple roles needed to teach online, faculty development for online instructors becomes very complex. The faculty themselves, or in collaboration with an instructional designer, must also present a sound interface design so that learners can find what they need, when they need it. Faculty may work with instructional designers or by themselves to create learning activities, design assessments, and develop course materials. Understanding how to interact with support staff is a best practice for e-learning development [14]. Use of new technologies is required to develop online courses, activities and communicate with distance technologies. E-learning tools, such as wikis, social media and virtual simulation, can engage students in the application of course concepts. As technology experts, faculty need to know how to use these tools, the course management system and various educational software. Mastering these skills can improve faculty attitudes and acceptance of online teaching.

\section{Evaluation of faculty development}

It is vital to plan for evaluation of faculty development programs early in the design process. Too often the evaluation of faculty development programs is not given the same attention as content. While a variety of evaluation methods have been described in the literature, a systematic review of nine leading publication sources known for reporting faculty development evaluation studies found only a limited number met best practice standards [16]. As might be expected, results of these evaluations indicated varying levels of effectiveness. The most commonly employed evaluation methods for faculty development programs are pretest/posttest, retrospective self-assessment, and independent performance ratings [17]. Use of evaluation embedded in the faculty development program is key to support change and monitor progress [18]. This is particularly true for programs of longer duration and those conducted using a blended approach (i.e., in-person sessions combined with distance technologies). Evaluation provides valuable feedback regarding the quality of the session, and has the potential to simultaneously improve faculty engagement [19].

\section{BEST PRACTICES IN FACULTY DEVELOPMENT}

Characteristics of successful faculty development programs build on previous activities, offer opportunities to discuss classroom experiences with others, are aligned with state and national standards, and encourage ongoing professional communication of instructors with similar concerns [20]. A systematic review of faculty development studies designed to enhance medical education found programs to be most effective when they incorporated experiential learning, provided feedback, included effective peer and colleague relationships, applied effective teaching learning principles, and used diverse methods [21]. Diverse methods for faculty development include seminar series, short-courses, workshops, and webinars. Faculty can benefit from formal and informal consultations from off-campus "experts," mentors, fellowships, and learning communities [22, 23].

\section{A. Online course management and technology}

Online faculty are expected to be experts in content knowledge as well as online course management. It is critical for faculty to feel confident with course management, since online students can sense when an instructor is less comfortable managing an online class or using course technology [24]. Students expect a well-designed course with quality materials, clearly defined expectations, relevant assignments and assessments aligned to learning objectives, and appropriate use of media.

To get faculty "up and running” with online teaching, university-wide faculty development programs are offered and focus on the technical "how to" of using the course management system. Such programs are 
typically delivered through centralized information technology, localized technical support, or learning technology support departments. From there, faculty are encouraged to attend workshops and seminars offered on campus and at conferences and workshops off campus, as resources permit. Some universities have used a "localized faculty-based approach" to deliver faculty development for online teaching, with staff in the school or department appointed to work with and give peer support to faculty adopting technologies in their teaching [8]. Others have learning technology and/or design support units staffed by instructional designers, media specialists, and instructional technologists.

Best practices of faculty development for instructional technology suggest that the focus be pedagogy, and not simply technology skill acquisition [25]. Such programs should include social and professional dialogue and be based on instructor work and experiences in the classroom [26]. Well-balanced faculty development programs that increase knowledge of pedagogy, course design, presentation of content and skills in the appropriate use of technology encourage development of quality online courses. Faculty development success in instructional technology has been correlated with high levels of teacher reflection and self-monitoring [27]. In addition, faculty development programs that build course management, facilitation, and time management skills lead to a more positive online experience for faculty and students.

\section{B. Learning communities: Communities of practice}

Faculty development has typically been an individual endeavor intended to further one's professional interests, areas of weakness in pedagogy, or research foci. Collaborative approaches, however, can be more cost effective, efficient and facilitate deeper learning among faculty. Faculty learning communities, also referred to as communities of practice, provide an active, connected approach with the potential to enhance and expand professional growth opportunities. A community of practice (COP) is defined as a group of people who share an interest in a domain of human endeavor and engage in a process of collective learning that creates bonds between them [28]. The three main characteristics shared by a COP include: 1) domain (shared knowledge and competence in the focus area), 2) community (interactive members learning together), and 3) practice (shared repertoire of resources, tools and experiences) through which the repeated exchange of knowledge and experience moves the practice of teaching and learning forward. A COP may operate formally or informally and be cohort or issue focused. A COP may be within a single institution (the most common type), a multi-institution setting or on a global scale. Examples of global COPs are listed in Appendix A. This article describes a multi-campus faculty development COP model.

\section{AN INNOVATIVE APPROACH TO FACULTY IN E-LEARNING}

In an effort to enhance faculty attitudes, knowledge, skills and role acquisition in e-learning and technology in nursing education, a faculty development program employing a multi-campus COP approach was begun in 2006. The Wisconsin Technology Enhanced Collaborative Nursing Education grant (US Department of Health and Human Services, Health Resources and Services Administration [HRSA] Project \# U1KHP07714) provided support over five years for faculty development and infusion of technology into nursing education [29]. Nursing faculty, referred to as "scholars," from each of the five University of Wisconsin (UW) campuses who taught in a collaborative online Bachelor of Science Degree in nursing completion program, participated. The campuses were: UW-Eau Claire, UW-Green Bay, UW-Madison (principal investigator), UW-Milwaukee, and UW-Oshkosh.

The grant proposal incorporated a specific domain topic for each of the five years based on baccalaureate nursing faculty needs that were identified in the literature. The topics included telehealth, simulation, virtual gaming, problem-based learning and e-learning. The faculty development structure included monthly videoconferences among scholars, annual face to face conferences, campus leadership, and participation in online Desire2Learn $(\mathrm{C}$ (D2L) courses. Relevant and challenging assignments and scholar collaboration and interaction were encouraged in reflective discussions, both online and during videoconferences. A hub or bridge supported by UW-Madison coordinated synchronous videoconference 
Faculty Development for E-learning: A Multi-campus Community of Practice (COP) Approach

broadcasts to the scholars on each of the five campuses across the state of Wisconsin and was located at a sixth site in the state. Technology support staff were available during videoconferences at the hub and at each local videoconference site.

Each UW campus had a site leader who coordinated the campus budget and faculty development activities. A major role of the site leader was to maintain regular communication with scholars about the schedule of videoconferences, as well as serving as a resource to answer questions and directing scholars to available resources. Some campuses maintained the same site leader across the five-year grant period while other campuses changed leadership a number of times. Compensation for site leaders (e.g., course release, monetary) varied and was determined by individual campuses.

\section{A. Framing the e-learning faculty development program}

The fifth and final faculty development year of the grant addressed e-learning and was planned by the UW-Green Bay campus [30]. Two years prior to implementing the e-learning faculty development year, a planning committee of eight scholars was developed which included instructional technology designers, nursing faculty and staff, and the UW-Green Bay site leader. Given that most successful faculty development programs include a comprehensive approach, the committee selected an organizing framework upon which to base the learning objectives, topics and presentations for the year-long faculty development program [20,31].

The Flexible Framework for E-Learning by Badrul Khan was selected. The framework is composed of eight e-learning themes including: pedagogical, technological, interface design, evaluation, management, resource support, ethical and institutional [32]. Each theme in the framework is quite multi-dimensional, with constructs that overlap other themes. Five themes (one each month) were explored in videoconferences with the scholars. The remaining three themes of the framework were woven throughout the year and/or covered during the culminating face-to-face conference.

The term e-learning was defined for the faculty development program based on the framework and the literature review as: the use of network technologies to create, foster, deliver and facilitate learning any time, anywhere. The learning objectives for scholars during the faculty development year were also based on the framework. Scholars were exposed to issues and resources in online nursing education and able to self-evaluate practices based on the Flexible Framework for E-learning.

\section{B. Methods used in the e-learning program}

A detailed handbook was compiled and distributed to scholars at the start of the e-learning faculty development year. The initial handbook pages explained the framework, its eight themes, the definition of e-learning, objectives for the year, and scholar expectations (e.g., to complete monthly evaluation surveys). Directions for how to download, use and practice new technologies introduced during the year were included. A calendar of the videoconference dates and topics and information about the culminating faculty development e-learning face to face conference were given.

A D2L course for e-learning was created to house and disseminate information and resources, and to allow interaction among scholars. Prior to videoconference sessions, readings and/or preconference assignments were posted for scholars to access. Following videoconferences, session materials (e.g., PowerPoint presentations, recordings of videoconferences, etc.) were archived in the D2L course. Online discussion boards in the D2L course were used to continue dialog and ask questions between faculty development sessions. Resources and webliographies (the digital equivalent of a bibliography with online and hyperlinked information) were uploaded to the course for each of the eight framework themes.

\section{Monthly videoconferences}

Six one-hour monthly videoconferences were synchronously offered to scholars on each of the five campuses during the academic year. The Flexible Framework for E-Learning was introduced and explained to scholars during the first videoconference by its author, from his office located in Washington D.C. Content experts in five of the framework themes presented in subsequent months using similar web 
conferencing technology (Adobe Connect) through the videoconference hub to the five campuses from either remote locations or directly from the UW-Green Bay campus.

Presenters narrowed the scope of each theme of the framework for the one-hour videoconference sessions. For example, the review of the literature indicated the topic of facilitating online discussions was of great interest for faculty [4]. The e-learning issue of pedagogy presented in one videoconference was therefore limited to the topic of online discussions only.

\section{Educational technologies}

Integrating several instructional technology methods (i.e. Twitter) into the e-learning faculty development program allowed the scholars to gain experience with the technologies as e-learners. Experience using a new technology allowed scholars to build on their previous experiences in subsequent videoconferences or future online teaching endeavors, as suggested by Birman, et al. [20]. The planning committee determined which technology to feature each month based on the content and expected learning outcomes. For example, a speaker was chosen to explore the area of e-learning ethics and address whether certain virtues and attitudes could be effectively modeled by faculty to students in the e-learning environment. It was anticipated that this topic may elicit strong emotions and discussion. Twitter $\bigcirc$ was selected to provide a safe and anonymous way for scholars to opine thoughts, while using a new elearning technology. Other technologies used throughout the faculty development year included Skype, Adobe Connect, Polleverywhere.com, and Prezi. Tutorial video links and handouts of instructions for using new technologies were distributed to scholars in the e-learning handbook, the D2L course and through email reminders about upcoming videoconferences. Time to practice and ask questions about the new educational technologies was provided during e-learning videoconferences.

\section{E-learning conference}

The e-learning year of faculty development culminated in April 2011 with a two-day conference entitled, E-Learning in Nursing: Design, Innovation, Delivery and Evaluation [33]. Examples of the best elearning and technology innovations in nursing education from each of the five campuses were showcased on day one of the conference. For example, how to use a wiki in a nursing management and leadership course was demonstrated. Students in this course were placed in groups to create a wiki as a means to share and discuss state and national agencies and organizations that influence policy. In evaluating the use of the wiki in the course, one student commented "This wiki assignment really helped broaden our learning environment." More than $50 \%(\mathrm{~N}=65)$ of the students involved stated the wiki information was useful to them now or in the future. References to free wiki websites were also shared with faculty, such as PBworks, Wikispaces, Wetpaint and Wikidot.

The first day of the conference ended with a presentation by a nationally renowned nursing educator who spoke about future technology in nursing education and practice. Day two of the conference featured keynote sessions on the global application of the Flexible Framework of E-learning, interface design, scholar evaluation of e-learning dimensions, and technology sustainability in nursing education. Breakout sessions were presented in hybrid format (either face-to-face or webinar) on e-learning and academic integrity, disability services, student diversity, legal issues, faculty overload, and the 2011 Horizon Report (an annual update of innovative and useful technologies in education).

\section{Evaluation}

Evaluation was an integral component of e-learning faculty development in this multi-campus model. An evaluation instrument was developed by the e-learning planning committee to capture scholars' understanding and practice in e-learning. New items were developed around themes in the Flexible Framework of E-Learning by Khan. These ninety-five items were adapted and organized into discrete online surveys (approximately 18 question items per survey) related to each of the eight framework themes and were distributed to scholars via an email link prior to each videoconference. Qualtrics ${ }^{\odot}$ survey software was used, and scholar participation was monitored closely through planned email reminders sent to those who had not completed the survey at weeks one and two post videoconference. In 
Faculty Development for E-learning: A Multi-campus Community of Practice (COP) Approach

an effort to improve the response rate, scholars were offered a chance to win incentives, if all of the monthly surveys were completed. Scholars also completed a final survey evaluating the year of e-learning faculty development at the end of the face to face conference. Items in this survey asked scholars to score the impact of the faculty development year on their understanding of e-learning issues. Scholars were also asked to identify ways they had applied or planned to apply new e-learning knowledge, skills and attitudes.

This year-long e-learning faculty development program brought faculty into the role of e-learning students with opportunities to explore new content, participate in discussions and assignments in a D2L course, learn and practice innovative technologies, and overcome the learning curves associated with elearning and various technologies [26]. Self-reflection became an important tool for faculty as they processed their new role and paradigm shift, which effectively engaged faculty as suggested by Sarikaya, Kalaca, Yeen and Cali [17]. Completing the surveys offered faculty the opportunity to assess their online teaching practices with the potential to improve their self-efficacy in online teaching. Aggregate results of all scholar responses were shared during the annual conference and campus-specific results were provided to each campus leader.

\section{LESSONS LEARNED}

Despite the successes identified in the evaluation of the year-long process of faculty development in elearning, challenges were also encountered in the areas of faculty, technology, and financial resources. The campus site leader structure provided an informal and important source of feedback about how scholars experienced the faculty development year. Challenges and successes encountered by scholars were communicated to campus site leaders. Leaders discussed and addressed these concerns and achievements in monthly site leader teleconferences.

\section{A. Faculty}

Just as online students experience frustration and growth in moving to online learning, faculty communicated some frustrations and feelings of inadequacy with new educational technologies and social media used during the videoconferences. Scholars reported appreciation of the support received from WI TECNE leaders when implementing new technologies, the clear expectations for how the technology would be used, instructions for using new technologies, practice time, and opportunities to explore what worked and what could be improved [24]. As Geoghegan found with faculty in 1995, not all scholars were early (or easy) adopters of e-learning technologies [10]. Learning curves were steep during the faculty development year for some technologies, but were overcome by building on previous skills, using online discussion forums and consulting with campus site leaders. Many scholars noted that exposure to a variety of technologies empowered them to seek out and use additional technologies in their nursing education careers. Scholars described recruiting other faculty to increase participation in e-learning at their institutions.

Time and sustaining engagement in the year-long faculty development program were realities of this endeavor. Scholars expressed in the monthly surveys their interest in e-learning content but difficulty on some occasions preparing for and attending videoconferences and taking advantage of all the program resources available due to competing schedules. It was critical that site leaders were creative and persistent in fostering continued excitement and engagement of scholars. Prior to each videoconference, the planning committee used a variety of strategies to entice scholars to prepare and participate in videoconference sessions. For example, an engaging audio teaching tip (audio file recorded in a PowerPoint) was e-mailed to scholars prior to the videoconference on pedagogical issues. Thoughtprovoking case scenarios related to ethical issues in e-learning were sent to scholars and posted in the D2L course prior to the ethics in e-learning videoconference. A final example of engagement involved advertisement an expert speaker on institutional issues in e-learning from a nationally renowned online learning campus. 


\section{B. Technology}

There were variations in the type, age, quality, and support of the technology available on each of the five campus sites as well as the hub site coordinating the videoconference signals. Some campuses had permanent videoconference rooms with stationary equipment accessible at the flip of a switch, while others used a variety of classroom settings and portable equipment that involved more set up and technology support. Technology support staff knowledge, experience, and availability during videoconferences varied among campuses. Some campuses did not have telephone lines or Internet access in the videoconference room, causing difficulty when troubleshooting technology issues during a synchronous videoconference was required. Lack of Internet access in some of the videoconference room sites, for example, also hindered scholars from Tweeting thoughts, adding opinions to a web-based poll, or accessing the D2L e-learning course during monthly sessions. Using personal smart cell phones was one option scholars utilized to overcome this barrier.

Other inventive options were employed when problems with videoconferencing software were encountered. For example, problems connecting to an expert presenter located in another state occurred using Adobe Connect due to variations in bandwidth speed of data transmission from the hub to the hosting UW Green Bay campus. This resulted in difficulty receiving audio from the expert presenter during the first session for some campus sites. To work around the problem quickly, the presenter's PowerPoint slides that were previously uploaded to the D2L course were accessed by scholars with Internet access in their videoconference sites. As a result of this experience, thorough pilot tests with technical support staff from each campus site including the hub and faculty development planning committee members were coordinated prior to subsequent videoconference sessions. Although time consuming and challenging to coordinate schedules between six sites and multiple personnel, the pilottests seemed to remedy broadcast issues in future video sessions.

\section{Financial resources}

Successfully orchestrating a multi-campus faculty development program required a good deal of resources, both monetary and human. While the videoconference costs were very reasonable, about \$50 total for the hub to coordinate (or $\$ 10$ for each campus), additional media charges for staff support and time in troubleshooting during the pilot tests could easily exceed $\$ 100$ per campus per month. Honoraria for expert presenters for monthly videoconferences averaged about $\$ 350$ a month and were another considerable cost. Some of these presenters were experts from off campus, while others were experts within the planning committee or at local participating campuses. Planning committee members invested many hours in planning committee meetings for two years prior to the e-learning year; attended pilot tests of technology; designed the evaluation tools; assisted in numerous details during the faculty development program and planned monthly videoconferences and annual two day conference. Assistance from a campus department experienced in conference planning was utilized to implement the year end conference.

\section{Evidence of a Successful Program}

The collaborative blending of instructional technology, media and diverse faculty expertise and funding resulted in a successful program. At the conclusion of the year-long faculty development, faculty described several enhancements to their online courses resulting from their participation as a scholar including the use of pre-course surveys to assess learners' technical skills, student cafes to increase engagement, and expressed intentions to redesign their online courses to reflect best practices. Likewise, nine out of ten (93\%) faculty scholars described enhanced knowledge and understanding of e-learning ( $\mathrm{X}=4.57$ on 5 point Likert-type scale with 1 being not at all and 5 being very much). Likewise, the majority (95\%) indicated participation enhanced their ability to evaluate design and delivery methods in online courses. The collaborative blending of instructional technology, media and diverse faculty expertise and funding resulted in a successful program. 


\section{MOVING FORWARD}

This multi-campus faculty development program benefitted five UW nursing programs. As the final faculty development year progressed, it was realized that the e-learning faculty development content and online resources available in the D2L course could be made available to faculty who taught online in other disciplines. Sustaining the knowledge, skills and engaged attitudes of faculty around e-learning is a desired outcome of any faculty development program, especially one that has invested significant resources. The e-learning D2L course contained a rich array of resources as monthly videoconferences and year end conference sessions were recorded. These recordings, photographs, assignments, webliographies, and related scholarly articles were been archived and are available for use by any discipline on campus through the Center for the Advancement of Teaching and Learning office at the University of Wisconsin-Green Bay.

An interactive website was created for online instructors and instructional designers outside UW-Green Bay to explore e-learning issues based on the Flexible Framework for E-Learning. Visitors to the website may mouse over each of the eight themes of the framework to view definitions and examples for each theme. Sample questions used in the self- evaluation Qualtrics ${ }^{\circledR}$ survey distributed to e-learning scholars are linked to the website which can be accessed at: http://www.uwgb.edu/witecne/. Faculty and instructional designers are encouraged to visit the website to complete a self-assessment of their own online teaching and institutional practices.

\section{CONCLUSIONS}

Faculty need ongoing professional development in e-learning, especially as technology changes rapidly and students are increasingly more tech savvy. Appropriate and sufficient training is not always available [11]. Ruiz, Mintzer and Leipzig, suggested that e-learning required competencies well beyond traditional instructional methods with a shift toward learner-centered approaches utilizing faculty as facilitators of learning rather than distributors of content [35]. Competencies in pedagogy and implementation allow faculty to be more effective as technology evolves. New models of faculty development for e-learning are needed.

The featured model discussed a multi-campus faculty development program, grounded in an e-learning framework that integrated teaching-learning technologies and involved scholars in self-assessment of elearning practices. Program success required administrative support from each participating campus, as well as dedicated faculty willing to invest time and energy to improve their understanding and comfort with e-learning, and use of educational technologies.

Best practices are key in faculty development design and impossible without financial and technology resources, such as those afforded through the HRSA grant funding. In addition to these resources, to replicate this model, one must be cognizant of the time required to plan and execute multi-campus virtual faculty development programs, best accomplished with a team approach. Evaluation, a critical component of any faculty development program, was not to be forgotten. While this program involved faculty selfreflection of individual and institutional attitudes, practices and support within the eight e-learning themes, it would be prudent to also evaluate virtual faculty development programs using a continuous improvement model. Faculty reported participation in this unique model substantially impacted their understanding of e-learning issues. With these concepts in mind, the multi-campus online faculty development program presented could be successfully implemented by other universities across disciplines.

\section{ABOUT THE AUTHORS}

Janet Reilly, DNP, APRN-BC, is an Assistant Professor in the Professional Program in Nursing at the University of Wisconsin, Green Bay, and has taught online courses for eight years. With a focus on innovative technologies in nursing education (specifically e-learning) and nursing practice, she coordinated a year of multi-campus faculty development and the culminating conference: E-Learning in 
Nursing: Design, Innovation, Delivery, and Evaluation.

Christine Vandenhouten, PhD, RN, APHN-BC, is an Assistant Professor of Nursing at the University of Wisconsin- Green Bay. She has facilitated the assessment and evaluation committee at two colleges and is sought out for her expertise in program evaluation.

Susan Gallagher-Lepak, RN, PhD, is an Associate Professor in the Professional Program in Nursing at the University of Wisconsin - Green Bay. She teaches online courses and publishes on innovation and pedagogy in online teaching.

Penny Ralston-Berg, MS, has designed online courses since 1997. She is currently an instructional designer for the Penn State World Campus and telecommutes from her home in Menomonie, WI. Her research interests include student perspectives of quality and how this impacts the design practice. She has also served on conference planning committees, the UCEA Research Committee and is currently a member of the Quality Matters Academic Advisory Council.

\section{REFERENCES}

1. Allen, I. E. and Seaman, J., Class Difference\$: Online Education in the United States, 2010, USA: Babson Survey Research Group, November 2010.

2. Garrison, D., Cleveland-Innes, M., and Fung, T. Student Role Adjustment in Online Communities of Inquiry: Model and Instrument Validation. Journal of Asynchronous Learning Networks 8(2): 61-69 (April 2004).

3. Killion, C., Reilly, J., and Gallagher-Lepak, S. Becoming an Onliner: Student Perceptions of Moving from Traditional to Virtual Learning. Online Journal of Nursing Informatics 15(1) (February 2011). http://ojni.org/issues/?p=139

4. Taylor, A. and McQuiggan, C. Faculty Development Programming: If We Build It, Will They Come? EDUCAUSE Quarterly 31(3): 28-37 (July-September 2008). http://www.educause.edu/EDUCAUSE+Quarterly/EDUCAUSEQuarterlyMagazineVolum/Faculty DevelopmentProgrammingI/163099

5. Dwyer, C. “Any Time, Anywhere” Faculty and Curriculum Development: Using Asynchronous Learning Tools Beyond the Classroom. The Sloan Consortium (n.d.). http://sloanconsortium.org/effective_practices/quotany-time-anywherequot-faculty-and-curriculumdevelopment-using-asynchronous-

6. Appana, S. A Review of Benefits and Limitations of Online Learning in the Context of the Student, the Instructor, and the Tenured Faculty. International Journal of E-Learning 7(1): 5-22 (January 2008).

7. McQuiggan, C. and Ragan, L. Preparing to Teach Online as Transformative Faculty Development. Presentation: $10^{\text {th }}$ Annual SUNY Online Learning (SOL) Summit, Syracuse, NY. PowerPoint Slide 13 (February 2009). http://www.slideshare.net/alexandrapickett/carol-mcquigganand-larry-ragans-faculty-development-learning-and-growing

8. Wilson, G. and Stacey, E., Online Interaction Impacts on Learning: Teaching the Teachers to Teach Online. In: Crisp, G., Thiele, D., Scholten, I., Baker, S., and Baron, J. (Eds.), Interact, Integrate, Impact: Proceedings of the $20^{\text {th }}$ Annual Conference of the Australian Society for Computers in Learning in Tertiary Education, Adelaide, Australia: ASCILITE, 2003. http://www.ascilite.org.au/conferences/adelaide03/program/conf prog index.htm

9. Rogers, E. M., Diffusion of Innovations, 4th ed., New York: The Free Press, 1995.

10. Geoghegan, W. Stuck at the Barricades: Can Information Technology Really Enter the Mainstream of Teaching and Learning? Change 27(2): 22-30 (1995). 
Faculty Development for E-learning: A Multi-campus Community of Practice (COP) Approach

11. Owusu-Ansah, A., Neill, P., and Haralson, M.K. Distance Education Technology: Higher Education Barriers During the First Decade of the Twenty-First Century. Online Journal of Distance Learning Administration 14(2) (Summer 2011). http://www.westga.edu/ distance/ojdla/summer142/ansah 142.html

12. Chaney, K., An Exploratory Study of the Relationship between Online Instruction and Faculty Development among Teacher Education Faculty, UMI ProQuest Dissertations \& Theses, Publication No. 3426653, 2010.

13. Weaver, D., Robbie, D., and Borland, R. The Practitioner's Model: Designing a Professional Development Program for Online Teaching. International Journal on E-Learning 7(4): 759-774 (October 2008).

14. Aleckson, J. and Ralston-Berg, P., MindMeld: Micro-Collaboration between eLearning Designers and Instructor Experts, Madison, WI: Atwood Publishing, 2011.

15. Goodyear, P., Salmon, G., Spector, J.M., Steeples, C., and Tickner, S. Competencies for Online Teaching: A Special Report. Educational Technology Research and Development 49(1): 65-72 (2001).

16. Kucsera, J. and Svinicki, M. Rigorous Evaluations of Faculty Development Programs. Journal of Faculty Development 24(2): 5-18 (May 2010).

17. Sarikaya, O., Kalaca, S., Yeen, B. C., and Cali, S. The Impact of a Faculty Development Program: Evaluation Based On the Self Assessment of Medical Educators from Preclinical and Clinical Disciplines. Advances in Physiology Education 34(2): 35-40 (June 2010).

18. Kudenko, I., Ratcliffe, M., Redmore, A., and Aldridge, C. Impact of a National Programme of Professional Development in Science Education. Research in Science \& Technological Education 29(1): 25-47 (April 2011).

19. Sutton, M., White, L., Mbizo, J., and Stewart, G. Assessment in Online Programs: Use in Strategic Planning for Faculty/Adjunct Development and Course Instruction to Improve Faculty and Student Engagement. International Journal of E-learning 9(1): 129-145 (January 2010).

20. Birman, B.F., Desimone, L., Porter, A.C., and Garet, M.S. Designing Professional Development That Works. Educational Leadership 57(8): 28-33 (May 2000).

21. Steinert, Y., Mann, K., Centeno, A., Dolmans, D., Spencer, J., Gelula, M., and Prideaux, D. A Systematic Review of Faculty Development Initiatives Designed to Improve Teaching Effectiveness in Medical Education: BEME Guide No. 8. Medical Teacher 28(6): 497-526 (September 2006).

22. Rubeck, R. F. and Witzke, D. B. Faculty Development: A Field of Dreams. Academic Medicine 73(9): S32-S37 (1998).

23. Steinert, Y. Faculty Development in the New Millennium: Key Challenges and Future Directions. Medical Teacher 22(1): 44-50 (2000).

24. Ralston-Berg, P. Does Quality Matter to Online Students? Keynote Address: Second Annual Quality Matters Conference, Chicago, IL. (June 2010). http://www.qmprogram.org/files/conference/keynote.pdf

25. Wang, M. Designing Online Courses that Effectively Engage Learners from Diverse Cultural Backgrounds. British Journal of Educational Technology 38(2): 294-311 (March 2007).

26. Signer, B. Online Professional Development: Combining Best Practices from Teacher, Technology, and Distance Education. Journal of In-service Education 34(2): 205-218 (June 2008).

27. Lloyd, M. and McRobbie, C. The "Whole Approach": An Investigation of a School-Based Practicum Model of Teacher Professional Development in ICT. Journal of Educational Computing Research 32(4): 341-351 (2005).

28. Shearer, P.D., Shea, T.P., and Kristensen, E. Online Communities of Practice: A Catalyst for Faculty Development. Innovative Higher Education 27(3): 183-194 (Spring 2003).

29. WI-TECNE. Wisconsin Technology Enhanced Collaborative Nursing Education (WI-TECNE). (2010). http://research.son.wisc.edu/tecne/

30. WI-TECNE. Year 5: UW-Green Bay E-Learning Technology. (2011). http://research.son.wisc.edu/tecne/year5.htm 
31. Berquist, W. and Phillips, S. Components of an Effective Faculty Development Program. Journal of Higher Education 46(2): 177-211 (March/April 1975).

32. Khan, B. A Framework for E-Learning. (2010). http://bookstoread.com/framework

33. WI-TECNE. E-learning in Nursing: Design, Innovation, Delivery, and Evaluation Conference Schedule and Topics. (n.d.). http://research.son.wisc.edu/tecne/elearning/

34. Khan, B., Managing E-Learning Strategies: Design, Delivery, Implementation and Evaluation. Hershey, PA: Information Science Publishing, 2005.

35. Ruiz, J.G., Mintzer, M.J., and Leipzig, R.M. The Impact of E-Learning in Medical Education. Academic Medicine 81(3): 207-212 (March 2006).

APPENDIX A: EXAMPLES OF COMMUNITIES

\begin{tabular}{|l|l|l|}
\hline Community & Description & URL \\
\hline Sloan-C & $\begin{array}{l}\text { Consortium offering conferences, webinars, } \\
\text { workshops, and certificates, as well as the } \\
\text { Sloan-C Commons discussion groups }\end{array}$ & $\underline{\text { http://sloanconsortium.org/ }}$ \\
\hline Educause & $\begin{array}{l}\text { Community of Practice offering conferences, } \\
\text { publications, and research; listserves } \\
\text { addressing a variety of focused information } \\
\text { technology topics, with a Teaching and } \\
\text { Learning section relevant for online faculty }\end{array}$ & $\underline{\text { http://www.educause.edu/cg }}$ \\
\hline $\begin{array}{l}\text { Penn State } \\
\text { Corld }\end{array}$ & $\begin{array}{l}\text { Community of Practice specific to faculty } \\
\text { development including resources, open } \\
\text { discussion, and special interest groups }\end{array}$ & $\underline{\text { http://psuwcfacdev.ning.com/ }}$ \\
\hline LinkedIn & $\begin{array}{l}\text { Professional networking community with } \\
\text { examples of relevant groups including: Games } \\
\text { and Simulations for Healthcare, Higher } \\
\text { Education Teaching and Learning, Online } \\
\text { Professionals: Teaching College Online and } \\
\text { Hybrid and Technology in Nurse Education }\end{array}$ & $\underline{\text { http://www.linkedin.com/ }}$ \\
\hline $\begin{array}{l}\text { The eLearning } \\
\text { Guild }\end{array}$ & $\begin{array}{l}\text { Community of Practice offering conferences, } \\
\text { online forums, publications, and research for } \\
\text { E-learning professionals }\end{array}$ & $\underline{\text { http://www.elearningguild.com/ }}$ \\
\hline
\end{tabular}

